\title{
ЕКОНОМСКИ МОДЕЛ НА ПОВРЗАНОСТ НА ТЕРОРИЗМОТ И НА ТРАНСНАЦИОНАЛНИОТ ОРГАНИЗИРАН КРИМИНАЛ
}

\section{Крашка сооржина}

\begin{abstract}
Денес сѐ йовеќ е виялива инфилитрацијайа на мет́tунароянийе иерористички іруйи во светискийе финансиски йекови и мећунарояниой

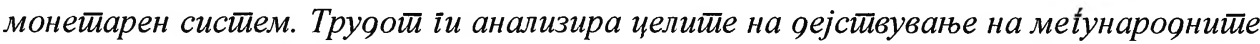
иерористичкки оріанизачии кои се йоместиваай оо йсихолоики ефекии на креирање

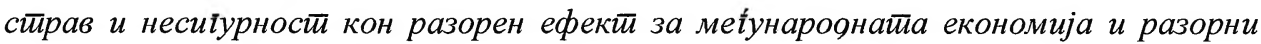
еколошки йослефичи. Со оілея на можностиа оа се ироизвеяай кайастирофални

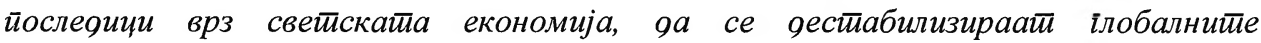

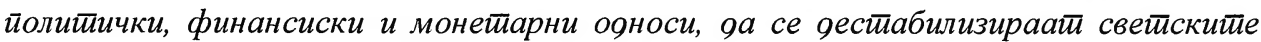
иеккови на кайийал и инвестичии, яа се заірози ілобалнайа безбеяносй, зайочнува

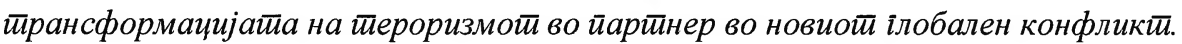

$\begin{array}{llr}\text { Клучни зборови: } & \text { ЕКОНОМСКИ МОДЕЛ, } \\ & \text { ТРАНСНАЦИОНАЛЕЧ } \\ & \text { КРИМИНАЛ } & \end{array}$

\section{Вовеg}

Анализата на врските помеѓу транснационалниот организиран криминал/тероризам/власт, како на државно ниво така и на ниво на „држава внатре во државата“, покажува дека во современиот свет постои моќна тајна врска помеѓу безбедносните и разузнавачките организации која е формирана на државно ниво, меѓународни криминални мрежи и квазидржави во форма на сепаратистичко движење или некои терористички организации. Овие „алтернативни државни ентитети“ го предизвикуваат суверенитетот, економијата и монополот на силите на целата протекционистичка фабрикација на изградената држава. Организираните криминални здруженија се изедначуваат со овие движења на сличен начин како и инфилтрирањето во државната администрација преку корупција и црна економија (M. Findlay, 2004).

Таквата поврзаност сѐ повеќе се темели на симбиоза и нековенционални односи помеѓу мрежите на транснационалниот организиран криминал и терористичките организации, а посебно кога станува збор за давање поддршка на терористите во доменот на логистика. 


\section{Економска либерализација: йоврзување на йранснационалниой оріанизиран криминал и йероризам како несакана йослеgица}

Економската либерализација, односно замената на планската економија со пазарна, овозможува полесен проток на добра, вклучувајќк наркотици и луѓе-жртви на трговија. На тој начин, преку губење државна контрола над протокот на добра, услуги, информации и капитал, се охрабрува и легалната и илегалната економска активност.

Организирањето и планирањето како неопходни елементи за дејствување на тероризмот егзистираат под покровителство на три основни стопански структури. Разработени се следниве методи на економски развој на тероризмот:

1. државно финансиран тероризам - кој има тенденција на опаѓање на меѓудржавно ниво, но сѐ уште е активен на внатрешно државно ниво (континуираната загриженост околу финансиската помош на Иран за разни организации и групи од Блискиот Исток);

2. приватизиран тероризам, каде што терористичките организации одлучуваат, или се принудени на тоа, да создаваат квазиавтономија преку државата (финансиите и ресурсите се насочуваат за реализација на терористички активности, како што беше случај во Авганистан и во Чеченија);

3. третото и највисоко ниво на економска организација е глобалната терористичка мрежа (Ал Каеда и нејзини сродни групи, кои ги користат поволностите што ги нуди глобализацијата и либерализацијата на трговските граници) (L. Napoleoni, 2004).

Со воведување зголемен и соодветен надзор во банкарското работење и финансиските трансакции се спречува во одреден степен перењето на пари, а со новата правна регулатива се олеснува, односно овозможува, замрзнувањето и конфискацијата на имотот и финансиските средства на осомничените за терористички активности или помагање на терористичките организации. На тој начин се создава нова ситуација во која сѐ поинтезивно почнуваат да се поврзуваат терористичките групи и организираниот криминал и да формираат сојузи. Зад таа спрега, како и со користење на дијаспората и добротворните организациии, се остваруваат големи финансиски средства кои се надвор од сите можни контроли од страна на легалните институции. Во такви услови, кога е зголемен меѓународниот надзор во поглед на финансиските текови и перењето пари, терористичките организации сѐ почесто ги користат помалку вообичаените механизми на финансирање (на пример, незаконска трговија, фалсификување пари, трговија со дрога и употреба на драгоцени метали). Оваа појава е темел, основа на Гудхартовиот закон, кој ја признава можноста за замена на методите на финансирање од оние што се строго регулирани кон финансирање преку помалку регуларни канали (A. Chrystal and P. D. Mizen, 2001).

Технолошките и организациони можности за формирање глобални мрежи го трансформираа и му дадоа моќ на организираниот криминал. Неговата фундаментална стратегија долго време се состоеше во навлегување во националните и во локалните државни институции за да ги заштити своите активности. Тоа е и понатаму важен елемент во оперативните процедури на организираниот криминал: може да опстане само врз основа 
на корупција и заплашување на државниот персонал, а понекогаш и на државните институции. Но, во поново време глобализацијата додаде уште еден, решавачки момент во институционалната стратегија на организираниот криминал - голема подвижност и екстремната флексибилност на мрежите им овозможува да ги одбегнат националните прописи и ригидните процедури на меѓународната соработка на полицијата (M. Castells, 1998).

Транснационалниот организиран криминал претставува закана и за националните економии. Негова основна цел е потчинување на националните економии во рацете на криминалните групи, користејќи ги, притоа, актуелните состојби и односи во новиот светски економски поредок. Транснационалните криминални организации остваруваат чисто економски интереси, додека инволвирањето во политиката претставува само начин и механизам за успешно реализирање на нивните економски стратегии.

Потчинувањето на националната економија од структурите на транснационалниот организиран криминал води до една крајно сложена и тешко поправлива ситуација во која енормно се ограничуваат можностите за нејзино успешно управување. Долготрајното извлекување максимални профити од растечката црна економија во голема мера го стимулира нејзиното регенерирање/репродукција. Како нов тренд во оваа сфера можеме да го потенцираме и интелектуализирањето на економскиот криминалитет преку заземање на клучните места од лица-експерти со највисоко образование и со големо професионално искуство во оваа значајна сфера.

Транснационалниот организиран криминал претставува сериозна закана и за функционирањето на финансиските институции, посебно во банкарскиот систем. Нивната интенција во оваа сфера е да се извршат продори во нивните сметки и да создадат услови за прикривање на незаконските парични трансфери, а нивните финансиски комбинаторики може во голема мера да ја ослабат стабилноста на банките.

Со подетална анализа на организираниот криминал се препознава структурата на здружението и транснационалниот профит/трговија на кој се потпираат (V. Duyne, 1993). Оваа анализа произлегува делумно од вреднувањето на организираниот криминал како покритие на добра и услуги на нелегалните пазари, инфилтрирање во државните и легалните пазари преку корупција и создавање и финансирање квазилегитимни бизнисздруженија (V. Volkov, 2002). Низ призмата на теоријата за здруженијата најдоброто што може да се каже за вакви врски е дека економскиот профит е заедничка платформа за две потполно различни цели. Гледано во ограничен контекст, далеку од идеолошки и политички императиви, примената на теоријата за претпријатие-тероризмот како дел од организираниот криминал нуди можност за:

-

- разбирање на фазите и локациите на 'трговијата“" на терор;

- идентификување и вреднување на материјална мотивираност за терористички напади;

- изложување и регулирање на финансирањето на тероризмот кое може да се разликува од религиозна, културна и политичка мотивација; 
- да се разбере зошто одделни фази од терористичкиот чин и неговата организациона структура се лоцирани во одредена судска надлежност; и

- $\quad$ го следат правецот на комуницирање што е од витално значење за терористичкиот чин и за подобро да се разбере селекцијата на жртвите на терористичкиот напад и неговата ранливост.

Моделот на организиран криминал базиран на ограничени докази со нагласка на структуралниот премин помеѓу легалните и нелегалните комерцијални здруженија ги поддржува актите на тероризам повеќ отколку нивната неморалност, исто така, го квалификува доменот во кој кривичниот закон ќе има поголемо влијание во регулирање на тероризмот отколку војската или политичките агенди (P. Dickie, 1994). Намерата на Меѓународната конвенција за супресија на финансирањето на тероризмот била јасно насочена за да се охрабрат сличните меѓународни одговори на кривичното право и оние што се сега насочени кон корупција и перење пари и последователно против тероризмот. Проблемот со овој пристап кон финансирањето на тероризмот е неговата прекумерна примена и способноста сите спонтани и политички мотивирани терористички насилства да се гледаат од аспект на финансирање. Во однос на меѓународната политика, објаснувањето за ова лежи во криминализацијата на напорите да се одземе правноста на оспорените идеологии (M. Tan, 2003).

Економската либерализација, социјалните разлики и подобрените комуникации во комбинација со слаби влади, корупција и невработеност во земјите во развој обезбедуваат услови транснационалниот организиран криминал да остане системски фактор во глобалната економија (L. Brynjar, 2005).

Може јасно да се критикува селективниот избор на еден тип тероризам наспроти друг, доколку тероризмот се смета повеќе за криминал отколку војна или револуција. Ако тероризмот е јасно интегриран во други криминални ентитети (како што се шверцување оружје, кражба на идентитет и перење пари), потоа, до ограничен домен, може да се применат ефективни пазарни регулативи во негова контрола дури и онаму каде што насилствоте е средство за трговија (M. Findlay, 1986).

Структуралните причини, поврзани со развојот на либералната (глобална и локална) пазарна економија и војна, имале значајна улога во создавање различни илегални пазари. Директните предизвици за државата се поставени од:

1. прикриени организации, полуавтономни разузнавачки агенции, тајни друштва и моќни елити кои може да бидат добро интегрирани во овластените државни институции;

2. криминални структури и здруженија што постојат во паралелна симбиоза со државата и може да ја спонзорираат или да ја земат под закрила;

3. револуционерни и терористички движења посветени на отфрлање на овластената држава и бараат територијална контрола и суверените, како и евентуално морален и легален статус (M. Findlay, 2008). 


\begin{tabular}{|c|c|c|}
\hline $\begin{array}{l}\text { Економски модел } \\
\text { на поврзаност на } \\
\text { тероризмот и } \\
\text { транснационалниот } \\
\text { организиран } \\
\text { криминал } \\
\end{array}$ & Импликации & Очекуван резултат \\
\hline Пазарни динамики & $\begin{array}{l}\text { Организираниот криминал } \\
\text { реагира на пазарните } \\
\text { динамики и ги користи } \\
\text { барањата за добра и } \\
\text { услуги, посебно во } \\
\text { забранетите пазари }\end{array}$ & $\begin{array}{l}\text { Криминалните организации } \\
\text { стануваат главни учесници во } \\
\text { различни криминални пазари, но, } \\
\text { сепак, нема да воспостават } \\
\text { монопол над овие пазари }\end{array}$ \\
\hline Претприемачки модел & $\begin{array}{l}\text { Криминалните } \\
\text { организации дејствуваат } \\
\text { како незаконски } \\
\text { претпријатија и бараат } \\
\text { нови бизнис-можности, } \\
\text { структури и стратегии за } \\
\text { зголемување на профитот }\end{array}$ & $\begin{array}{l}\text { Криминалните претпријатија } \\
\text { бараат разновидни пазари и } \\
\text { продукти за да го заштитат } \\
\text { профитот (преку off-shore } \\
\text { финансиски центри), преку } \\
\text { соработка со други криминални и } \\
\text { терористички организации, преку } \\
\text { договори со индивидуи, } \\
\text { институции и агенции во } \\
\text { незаконскиот свет }\end{array}$ \\
\hline
\end{tabular}

Препознавањето на растечката моќ на овие групи, особено во трговијата со дрога и тероризмот, е важен аспект на анализа поради нивната дијаметрална спротивставеност со легитимните државни интереси. Тоа е сложена меѓусебна поврзаност на држави, ослабени држави, „држава внатре во државата“, затворени држави што ја предизвикуваат репрезентацијата на организираниот криминал и тероризам и секогаш се во натпревар со овластените државни интереси. Секако, ако се концентрираме на економските димензии на организираните криминални здруженија и нивната вмешаност во „држава внатре во државата“", тогаш предизвикот за државните институции и процесите поставени од ваквите групи е сѐ позначаен. Во некои држави сивата економија ја надминува формалната економија според условите на ГНП, како и капиталните резерви.

Трипартиската врска помеѓ институциите на „држава внатре во државата“ во овластените држави, криминални мрежи и квазидржавни проекти е систематска со широка основа и е влијателна. Тоа значи дека едноставен притисок од страна на службите за спроведување на законот за да се прекине врската помеѓу тероризмот и организираниот криминал и финансирањето нема да има долгорочно влијание на стабилноста на власта која е под удар. 


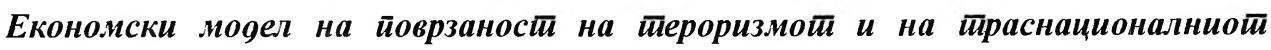
оріанизиран криминал

Хипотетички претпоставуваме дека групата може да учествува во два вида активности (терористички и криминални). Првата цел - набавка на општествени добра, кои се од корист на целата заедница и, второ, квазиопштествени добра, кои ја промовираат благосостојбата само на членовите од групата. Друга претпоставка е дека општествените добра се постигнуваат преку алтруистички акти на тероризам, со оглед дека квазијавните добра се стекнати со учество во криминални активности.

Каде што К = корисност добиена од страна на група која се вклучува во два типа активности - терористички и криминални.

$\mathrm{O}=$ општествени добра (придобивки за целата заедница, без оглед на учеството); КВ = квазиопштествени добра (придобивки за членовите на групата и лидерството); по = релативна тежина поставена од страна на организацијата за постигнување на општествени добра (O); пк = релативна тежина поставена од страна на организацијата за постигнување на квазиопштествени добра (КВ).

Бидејќ групата може да се ангажира во набавка било за општествени добра или за квазиопштествени добра, може да се напише: по + пк $=1$ (D. K Gupta, J. Horgan, A. P. Schmid, 2009).

Терористичката група се дефинира според нејзината примарна потреба за обезбедување општествени добра, и тогаш по > пк. Сепак, треба да се забележи дека сите терористички организиции немаат силна идеолошка позиционираност. Групите како што се Ал Каеда и Хамас дејствуваат од силна идеолошка позиција, додека други организации како што Абу-Сајаф и ФАРК во Колумбија имаат тенденција за поголема инволвираност за стекнување финансиска корист за нивното членство. Затоа ретките групи, кои се чисто идеолошки, ке имаат тежина од по $=1$; пк $=0$. За криминалните групи по $<$ пк и оние што се чисто криминални, по $=0 ;$ пк $=1$.

Додека за групите што дејствуваат со комбинирани мотиви, релативната тежина за двете е поголема од 0. Бидејќ е невозможно организијата да биде окарактеризирана како чисто алтруистична, може да се претпостави дека терористичките организации ќе дејствуваат поради комбинирани мотиви, додека за криминалните групи ваквата конфузија на цели е ретко присутна. Релативната сила на идеолошката позиција на терористичката група ја рефлектира важноста која ја придаваат на своите активности. Ангажирањето/вклучувањето во криминални активности може да биде помалку ризично и повеќе профитабилно (особено за членовите на групата) во изборот на соодветна комбинација, раководството мора да ги процени ризиците на губење политички легитимитет како резултат на нивната тесна поврзаност со криминални активности.

Кога групата учествува во незаконски активности, ризикува да биде казнета (C). Овие коефициенти се дадени на терористичките групи како резултат на усвоените политики од страна на државните органи и имплементирани од агенциите за спроведување на законот и војската. 
Кога групата е вклучена во двата вида активности (терористички и криминални), се соочува со релативен трошок (РТ).

$$
\mathrm{PT}=\mathrm{O}+\mathrm{KB}=\mathrm{C}
$$

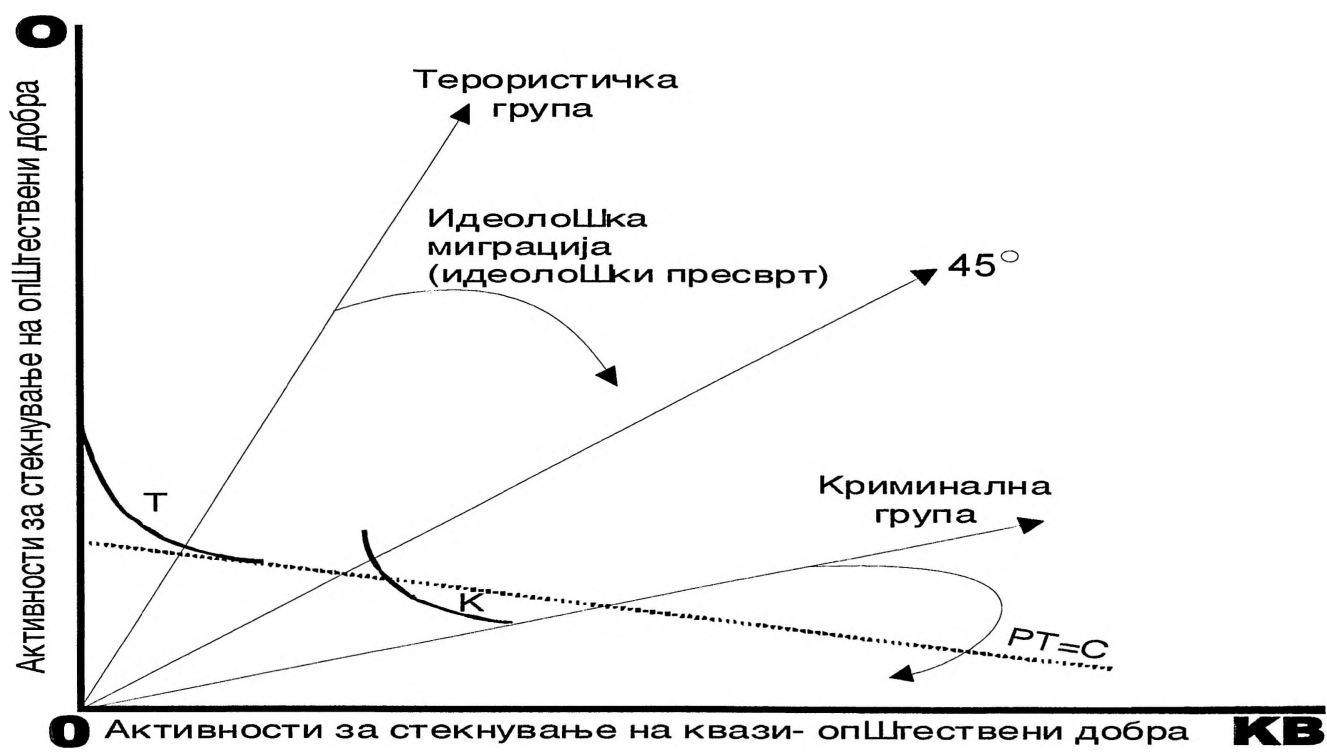

Претпоставуваме дека групата има способност да го апсорбира конечниот износ на трошоците настанати како резултат на незаконските активности. Оваа цена ги вклучува негативните санкции наметнати од страна на државните органи.

Преку претставената геометриска верзија на моделот претставен на Табела 1 сликовито се опишани наведените аргументи. Во дијаграмот, вертикалната оска ја мери корисноста која произлегува од групата која се стреми кон стекнување општествени добра, додека хоризонталната оска ја покажува корисноста од квазиопштествени добра. Линијата од 45 степени покажува еднаков приоритет за двата вида добра. Секоја позиција над оваа линија имплицира поголема корисност за стекнување општествени добра, додека секоја позиција под одредената линија го покажува спротивното. Терористичката група типично ќе демонстрира позиција прикажана преку независната крива (т). Спротивно, криминалната организација ќе одбере оптимална комбинација по независната крива (к).

Испрекината линија (РT) е аналогна на буџетско ограничување, во која групата треба да избере комбинација на двете активности (терористички и криминални) со цел да ја максимизира сопствената корисност. Може да се потенцира дека наклонот на кривата претпоставува повисока цена наметната од страна на државата за вклучување во терористички активности (D. K Gupta, J. Horgan, A. P. Schmid, 2009).

Транснационалниот организиран криминал и тероризмот како крајно опасни општествено негативни појави претставуваат продукт на севкупните општественополитички и економски услови. Во тој контекст, логично е причините и корените за 
нивното манифестирање да ги бараме во суштината на тие односи и состојби, односно во начинот на функционирањето на институциите кои се карактеристични за конкретната држава и конкретниот општествен систем.

\section{Транснационалниот̄ оріанизиран криминал - нова економија на иерорисиичките мрежи}

Структурите на транснационалниот организиран криминал активно се вклучени во финансирањето на терористичките организации на глобално и на национално ниво, во снабдувањето со оружје и муниција и најсовремена комуникациска технологија, финансирање определени политички партии, инфилтрирање на „свои луѓе“ во највисоките државни органи, извршување одмазднички акции против органите и службите за безбедност во ситуација кога ќ бидат загрозени нивните криминални бизнис-интереси и воспоставени позиции. Во постконфликтните општества овие криминални структури се јавуваат како акцелератори на формите на т.н. криминален тероризам и претставуваат сериозен заканувачки фактор насочен против воспоставувањето и одржувањето на мирот и кон рушење на макотрпните мировни процеси.

За транснационалниот организиран криминал е значајно да се потенцира дека во определени ситуации може да се употреби и како моќно, многу валкано политичко оружје за извршување на следниве дејности:

- земање заложници или закана со терористички акции во другите земји;

- давање помош на терористите било во подготвителната фаза, во оспособувањето, или им се даваат засолништа при пребегнувањето или во периодот на мирување за прикривање, или при конкретните акции;

- испраќање свои единици командоси за егзекуција и терор во други земји;

- прикриено нанесување значителна штета на стопанството по пат на државниот план или со 'трпеливост“ преку изработка на огромни количини фалсификувани пари;

- изработка на фалсификувани исправи од сите видови;

- користење и насочување на стопанската шпионажа;

- користење посебни видови стопански бојкот;

- сеопфатно кршење нечии посебни права; и

- евентуално извршување шпионажа и др“ (А. Stumper, 1992).

Постојат многу современи правно поддржани шпекулации на регионално и на меѓународно ниво според кои транснационалниот организиран криминал е клучен спонзор за тероризмот. Повремените докази за перење пари поврзани со тероризам или преносот на криминални добра на адреса на терористичките организации или корпорации има тенденција да го оправда законски поддржаното уверување дека со регулирање на криминалните приливи на пари, тероризмот ке биде демантиран. Сепак, постојат голем број истражувања во врска со организираниот криминал и тероризам што може да ја тестираат оваа хипотеза. 
- Како и со организираниот криминал, премногу е едноставно и погрешно да се генерализира тероризмот и терористичките организации. Клучна разлика, онаа која можеби има директно влијание врз тоа дали терористичките корпорации бараат надворешен извор, е дали организацијата која е во заднина на тероризмот контролира територија или, пак, комерцијални имоти.

- Некои терористички случувања се спорадични, спонтани, индивидуализирани и бараат малку во поглед на пари за да ги промовираат и да ги постигнат целите.

- Многу од терористичките организации се признаени или легални политички движења и добиваат финансиска помош преку делба на ресурсите.

- Одредени организации за кои се знае дека имаат терористички цели или терористички сојузници може да добијат бенефиции преку донации од религиозни организации или движења на отпор.

- Некои терористи и нивните организации, исто така, имаат удел во криминални активности заради профит.

- Приходот од криминал е насочен во голема мера кон одржување на индивидуалниот животен стил отколку кон понатамошни терористички активности.

- Организираниот криминал и тероризам може финансиски и политички да профитираат преку дестабилизирање на пазарните структури, без генерирање препознатливи и заемно поддржани врски за трансфер на пари.

- Многу терористи и организации кои тие ги спонзорираат се независно богати преку легитимни бизниси или пренесено богатство, а нивниот легален капитал може да се пренасочи да спонзорира тероризам, или не, во зависност од ситуацијата (М. Findlay, 2008).

Ако криминалната соработка не е клучна за финансирање на терористичките организации, напорот да се победи тероризмот преку организираните криминални патишта е во погрешен правец. Ова сознание е потребно да се земе предвид отколку автоматски да ce претпостави дека со следење на трагата на парите ќе се спречат терористите во планирање и реализирање на терористичките операции.

Она што е спорно и што постојано се осознава во капиталните и финансиските договори на организираните криминални групи е тоа дека испитувањето на врските преку легални банкарски и финансиски сервиси може да се покаже доста продуктивно кога станува збор за разбирање (поради контрола) на финансирањето на тероризмот. Организираниот криминал и терористичките организации ќе врбуваат заеднички криминални корпорации за нивните сопствени особено сепаратистички мотивации. Добар пример за ова е илегалната трговија со оружје. Организираниот криминал профитира од производството, продажбата и маркетингот на илегалното оружје.

Денес, определени организации на транснационалниот организиран криминал почнуваат илегално да произведуваат некои типови лесно рачно оружје кое веднаш го пласираат на црниот пазар. Оружјето лесно го набавуваат и од фирмите за производство на оружје на слабите и корумпирани држави кои не се во состојба да обезбедат соодветна контрола. Исто така, порозните меѓународни граници, непрофесионализмот на структурите 
на интегрираното гранично обезбедување ги отвараат 'портите“ за влез или непречен трансфер на оружјето во сите региони на светот, посебно во кризните региони и постконфликтните држави во кои, покрај 'комунистичкото“ оружје, сѐ поприсутно е и оружјето произведено и во некои земји-членки на НАТО (М. Котовчевски, 2008).

Поврзаноста помеѓу тероризмот и организираниот криминал е овозможена преку широкораспространетата расположливост на мало и лесно оружје што може да биде шверцувано за пари или употребено во операции. Бидејќ производството на оружје во светот ги надминува потребите од редовно вооружување на армиите, остануваат огромни количества што се шверцуваат на илегалниот пазар. Како носители на шверцувањето се јавуваат поединци, компании, па и одредени држави, односно постојат три паралелни пазари за продажба на оружје: бело - се врши директно преку владите; сиво - преку приватни компании, но под надзор на владата; и црно - преку самостојни трговци и поединци (Т. Милошевска, 2009).

Кога ќе заврши незаконската трговија со оружје, парите што се добиени при продажбата поминуваат низ процесот „перење пари“. Оружјето, исто така, може да се употреби како валута за размена за наркотици. Сите овие трансакции резултираат во големи профити за криминалните организации и имаат далекусежни последици. Илегалното тргувано оружје често ги поддржува постоечките етнички и политички конфликти или агендите на терористичките групи, а со тоа претставува безбедносна закана како на национално така и на меѓународно ниво (R. Langhorne, 2006).

Всушност, не е невобичаено парамилитарните сили и герилците да го поттикнат регионалниот конфликт, да ја зголемат побарувачката за оружје, а со тоа да го зголемат нивниот економски просперитет преку трговија или шверц на оружје на други борци понекогаш и на нивните непријатели. Ова се оствари во Африка, на Балканот, во Латинска Америка и во Азија. Поголем дел од оружјето доага од поранешните советски држави и од Источна Европа. Незаконската трговија со оружје води кон тајно партнерство помеѓу воените сили и мафијашките групи во тие региони (L. Shelley, C. Corpora and J. Picarelli, 2011).

Терористите може да остварат корист од трговијата со оружје и преку дополнителен профит од обезбедување на трансферот на оружјето помеѓу различни терористички ќелии. Поврзано со ова е и заедничкото обучување и преносот на знаење што обезбедува поголем капацитет на терористичките организации. Комплексноста од оваа трговија и заемно помагање предизвикува причинско толкување на криминалните приходи и терористичките ресурси.

\section{Заклучок}

Во ерата на глобалниот тероризам, се вели дека светот се соочува со нов предизвик поставен од страна на транснационалниот организиран криминал; локални манифестации кои се нераскинливо поврзани со меѓународниот конфликт, а заканата е насочена против глобалната заедница. За да се контролира тероризмот во овие заедници, мора да се прекине финансиската врска со организираниот криминал. 
Многу е попродуктивно да се открие финансирањето на тероризмот и неговите организации за да се поведе иницијатива (лоцирана во криминалот и политиките) отколку да се базира спроведувањето на законот на популарни културолошки митологии за заедничките предизвици на државата. За да се документира ова, неопходно е да се истражи мотивацијата за профит на терористичките здруженија за да се зачува материјалното богатство (како со трговијата со дрога), како и политичката моќ и културното влијание во најширока смисла, кое може, од друга страна, да има материјални нуспродукти. Секако, критичните фази на терористичките организации може да се оквалификуваат како профитирачки. Ова се препознава во обидите да се формулира перењето пари и да се конфискуваат криминалните поседи како обид за да се спречи финансирањето на тероризмот. 


\section{Литерайура}

Brynjar, L (2005). Globalization and the Future of Terrorism, Routledge, London \& New York. Castells, M. (1998). End of Millennium, the Information Age, Economy Society and Culture, Vol. 3. Oxford: Blackwell.

Chrystal, A. Mizen, P. (2001).Goodhart's Law: Its Origins, Meaning and Implications for Monetary Policy, City University Business School, London.

Dickie, P. (1994). Organised crime: Towards a research-regulatory approach to organised crime, in D. Chappell and P. Wilson (eds), The Australian criminal justice system: The mid 1990' $s$, Sydney:Butterworths.

Duyne, V. (1993). Organised Crime and Business-crime Enterprises in the Netherlands, Crime, Law and Social Change, 19:103-142.

Findlay, M. (1986). Organised crime as terrorism, Australian Quarterly, 58(3): 286-296.

Findlay, M. (2008).Global Terror and Organised Crime: Symbiotic or Synonymous? Asian Criminology 3:75-89.

Findlay, M (2004). Globalisation of crime: Terror in a contracting globe, in V. George and R. Page (Eds), Global social problems, Cambridge: Polity.

Gupta, D, Horgan, J, Schmid, A. (2009).Terrorism and Organized Crime: A Theoretical Perspective, in David Canter (ed), The Faces of Terrorism, John Wiley \& Sons Ltd, UK.

Котовчевски, М. (2008), Облици на криминално дејствување на транснационалниот организиран криминал, во Зборник на трудови, Глобализащија, мирой $u$ безбеяносй $a$, Тони Милески (уред), Министерство за одбрана и Филозофски факултет, Скопје, 2008.

Langhorne, R. (2006). Global Politics, Oxford University Press Inc.

Милошевска, Т. (2009). Незаконската трговија со оружје и муниција како потенцијален безбедносен проблем, Гояишен зборник, Филозофски факултет, книга 62.

Napoleoni, L. (2004). Tracing the Money Behind Global Terrorism, Penguin Books, England.

Napoleoni, L. (2005). Terror incorporated: Tracing the dollars behind the terror networks. New York: Seven Stories.

Shelley, L, Corpora, C, Picarelli, J. (2011). Global Crime, Beyond Sovereignty; Issues for a Global Agenda, $4^{\text {th }}$ Edition, Maryann E.Cusimano-Love (Ed).

Stumper, A. (1992). Internacionale Kriminaliteta im Umbruch. Die Polizei, No. 7, Viesbaden.

Tan, M. (2003). Money laundering and the financing of terrorism, Journal of Banking and Finance Law and Practice, 14(2): 81-107.

Volkov, V (2002). Violent entrepreneurs: The use of force in the making of Russian capitalism. Ithica N.Y: Cornell University Press. 
Tanja MILOSHEVSKA

\section{ECONOMIC MODEL OF INTERATION OF TERRORISM AND TRANSNATIONAL ORGANIZED CRIME}

\section{Summary}

Today's is increasingly visible infiltration of international terrorist groups in the world financial flows and the international monetary system. This paper analyzes objectives of the activity of international terrorist organizations which are moving from the psychological effect of creating fear and uncertainty to devastating effect on the international economy and the devastating environmental consequences. Given the ability to produce catastrophic consequences for the world economy, to destabilize global political, financial and monetary relations, to destabilize global capital flows and investments, jeopardizing global security, begins the transformation of terrorism in partner in the new global conflict.

Keywords: ECONOMIC MODEL, TERRORISM, TRANSNATIONAL ORGANIZED CRIME 